\title{
Refractory Oropharyngeal Squamous Cell Carcinoma
}

National Cancer Institute

\section{Source}

National Cancer Institute. Refractory Oropharyngeal Squamous Cell Carcinoma. NCI

Thesaurus. Code C148385.

Oropharyngeal squamous cell carcinoma that does not respond to treatment. 